\title{
Income Inequality and Macroeconomic Volatility: An Empirical Investigation
}

\author{
Richard Breen ${ }^{\mathrm{a}}$ and Cecilia García-Peñalosa ${ }^{\mathrm{b}}$
}

14 July 1999

\begin{abstract}
:
Recently, there has been a resurgence in the interest in the determinants of income inequality across countries. This paper adds to this literature by examining the role of one further explanatory variable: macroeconomic volatility. Using a cross-section of developed and developing countries, we regress income inequality on volatility, defined as the standard deviation of the rate of output growth. We find that greater volatility increases the Gini coefficient and the income share of the top quintile, while it reduces the share of the other quintiles. The other variable that seems to play an important role is relative labour productivity, supporting previous findings.
\end{abstract}

Key words: income inequality, output volatility, cross-country regressions.

JEL Classification numbers: I30, O15.

a European University Institute, Badia Fiesolana, San Domenico di Fiesole, Florence, Italy, and Queen's University, Belfast BT7 1NN, UK.

b Nuffield College and GREQAM,. Corresponding author: Nuffield College, Oxford, OX1 1NF, UK ph: 441865-278656, fax: 44-1865-278621, email: cecilia.garcia-penalosa@ nuf.ox.ac.uk.

Ackowledgements: We would like to thank Tony Atkinson, Steve Redding, Jon Temple, and seminar participants at the University of Zurich. 


\section{Introduction}

In recent years, inequality in earnings and income has been the focus of attention as both the explanands and the explanandum of inquiry. On the one hand, there is a growing literature concerned with the impact of inequality on economic growth (see, for example, Perotti 1996). On the other, there has been a revival of interest in the factors shaping the distributions of earnings and income. This has taken the form of studies of the evolution over time of inequality within a country, discussed, for example, by Atkinson (1996, 1997) and Gottschalk and Smeeding (1997), and of analyses seeking to explain crossnational variation in income inequality, such as Bourguignon and Morrissson (1998) and Li, Squire and Zou (1998). It is to this latter strand that the present paper contributes.

The main issue that we address is whether macroeconomic volatility plays a role in determining a country's degree of income inequality. There are two reasons for asking this question. First, Ramey and Ramey (1995) have found that higher volatility of the rate of output growth is associated with a lower average growth rate. Their results raise the question of whether volatility also affects other macroeconomic variables. Second, Hausmann and Gavin (1996) have shown that Latin American economies are both much more volatile and much more unequal than industrial economies, and that in fact volatility of the level of GDP is positively correlated with inequality.

We explore this idea further, and in particular we compare the role of volatility in determining inequality with that played by other factors previously found to have a significant effect on inequality, such as macroeconomic dualism, financial development and civil liberties. Following Ramey and Ramey (1995), we use the standard deviation of 
the rate of growth of GDP over a 30-year period as our measure of macroeconomic volatility. Using data for a cross-section of countries over the period 1960-90, we find that volatility has a positive effect on income inequality, and that this relationship is robust to controls for a number of other factors that the literature suggests affect inequality. Furthermore, we show that the effect of high volatility is to increase the share of income of the highest quintile at the expense of (mainly) those in the second and third quintiles.

Our results are robust to the inclusion of the explanatory variables used in previous work, such as output levels, educational attainment, relative labour productivity, and civil liberties, among others. We find that of the variables previously found to explain inequality only relative labour productivity and the share of labour employed in agriculture have a consistently significant effect.

The organization of the paper is as follows. Section 2 describes existing hypotheses about the determinants of income inequality. Section 3 starts with a description of our dataset, which comprises a cross-section of 80 developed and developing countries. We then present our empirical results. Our basic results are extended to include other explanatory variables. We also examine a smaller dataset that allows us to control for initial inequality, and test for alternative measures of volatility. In section 4 we consider a possible explanation for our findings. Section 5 concludes. 


\section{The Determinants of Income Inequality Across Countries}

Over the past fifty years, several hypotheses have been postulated to explain differences in the distribution of income among countries. The first of these was Kuznets' argument (Kuznets, 1955 and 1963) that inequality increases in the early stages of development, but falls as industrialization goes on, as a result of the interplay between the rural-urban income differential and the share of the population in one or the other sector. This hypothesis would then imply that, at a particular point in time, we should observe an inverted-U shaped relationship between a country's level of development -proxied by per capita income- and its degree of inequality.

The Kuznets hypothesis has been subject to close scrutiny both from a theoretical and an empirical point of view. Anand and Kanbur (1993a,b) maintain that there are two major problems with it. On the empirical side, Anand and Kanbur (1993b) find no support for the inverted-U relationship on a cross-section of countries. They then argue (see Anand and Kanbur, 1993a) that this may be due to a theoretical misspecification. In particular, it is important to allow sectoral means and sectoral inequalities to change over time, and once we do this the evolution of inequality may follow many different patterns.

Bourguignon and Morrisson (1998) argue that the Kuznets process is too complex to be simply proxied by GDP per capita, and that both the rural-urban income differential and migration between the two sectors are endogenously determined. Under perfectly competitive labour markets the distribution of income in a country will be determined by factor endowments and the distribution of factor ownership. However, labour markets are seldom competitive and a more appropriate approach is to think of a dual economy model. In this framework, an indicator of the imperfection of the labour market- i.e. a 
measure of the extent of dualism in the economy- should help explain differences in the distribution of income. They propose the use of the relative labour productivity (RLP) between agriculture and the rest of the economy as a measure of dualism, and find, in a cross-section of developing countries, that the lower is RLP in agriculture the more unequal the economy. Measures of factor endowments, such as cultivable land per capita, seem to have no robust effect.

Other macroeconomic variables have been found to be associated with the distribution of income. In their study of the determinants of inequality, Li, Squire and Zou (1998) examine the impact of four variables: initial secondary schooling, civil liberties, financial development and the Gini coefficient of the distribution of land. They find that all these variables have a significant effect on the Gini coefficient: higher level of schooling, civil freedom and financial development reduce inequality, while the more unequal the distribution of land, the more unequal that of income. Bourguignon and Morrisson (1990) point to the role of trade liberalisation in increasing inequality. In particular, they find that trade protection plays a significant role. Lastly, Alesina and Perotti (1996) find a positive correlation between socio-political instability and inequality, although they argue that causation runs from the distribution of income to instability.

These papers provide us with a set of ideas about the possible determinants of income inequality. Our analysis of the influence of volatility on inequality must also test the robustness of its effect to the inclusion of these variables. 


\section{The influence of volatility on the distribution of income}

\subsection{The data}

Our analysis of cross-country differences in inequality is limited by the availability of data on the distribution of income. We draw on the Deininger and Squire (1996) dataset, which consists of a large compilation of country data for almost 200 economies. Each observation relates to a particular country in a particular year and includes the Gini coefficient of income and, for some cases, quintile shares. In general, there is no consistency in the surveys either across countries or over time within a country. Surveys differ in their coverage (national, rural and urban), income unit (household or personal income), the source of the calculations (income or expenditure) and whether it is gross or net income that they report. Following the arguments of Atkinson and Brandolini (1999), we do not consider only the "high quality" subset of the Deininger-Squire data set. Instead, we select all the observations that were obtained from surveys of national coverage (see the appendix for a more detailed description of the data).

The data within our subset still presents a problem because the income units, the source of income and whether it is measured net or gross of tax all differ among the observations. One means of dealing with these differences is to "adjust" the data by calculating the difference between, say, the average Gini coefficient of household and the average Gini coefficient of personal income, and then adding it to those observations that report household income (Perotti (1996) and Li, Squire and Zou (1998) adjust the data in this way). The drawback of this approach is that the adjustment coefficients depend crucially on the sample chosen. Instead, we will follow Bourguignon and Morrisson 
(1998) and include dummy variables in our regression equations in order to control for these differences.

To obtain a measure of volatility we calculate the annual rate of growth of real per capita GDP over the period 1960 to 1990 . Output volatility is then defined as the standard deviation of the annual growth rate, as done by Ramey and Ramey (1995). This is in contrast with Hausmann and Gavin (1996), who define macroeconomic volatility as the standard deviation of the level of GDP per capita. The problem with using the latter measure of volatility is that an economy which is growing at a high but constant rate will nevertheless display high volatility. Given the variety of growth patterns observed within our sample, we prefer a measure which is not sensitive to growth in this way.

There are 80 countries for which we have data on inequality and GDP for the period. Our sample incorporates 22 developed countries, 17 Latin- and CentralAmerican, 5 New-Industrialising countries, 11 other Asian countries, and 25 African economies. Table A.1 in the appendix gives the list of countries.

\subsection{Basic results}

Figure 1 presents a scatter plot of the Gini coefficient against output volatility for the 80country sample. A simple regression of the Gini coefficient, denoted $G_{i}$, on volatility, $S D_{i}$, and its square yields the following equation

$$
E\left(G_{i}\right)=18.879+8.278 S D_{i}-0.590 S D_{i}^{2}
$$

( $R^{2}=0.224$, standard errors in parenthesis). This simple regression equation is capable of explaining a substantial fraction of the variation in inequality across countries. Countries where output is very volatile are more unequal, except for very high levels of 
volatility. The partial derivative of $G$ with respect to $S D$ is positive for all values of the latter less than 7. For greater volatility, the relationship seems to break down. In fact, when we divide our sample into two subsets, we find that for the 16 observations with a value of $S D$ above 7 there is no significant relationship between volatility and inequality.

\section{Figure 1 and Table 1 around here}

Table 1 reports 6 regressions run on the Gini coefficient of the distribution of income in 1990. All equations in table 1, as in the rest of the paper, are OLS estimations with heteroschedasticity consistent errors. We included three dummy variables (for net income, for household income, for expenditure measures) in order to control for differences in the measurement of inequality. Of these only the dummy for net income has a significant coefficient. Our basic equation, column 1 , is then augmented to test for the robustness of the effect of volatility to the inclusion of two standard variables: the Kuznets effect and education. A simple regression of the Gini coefficient on the level of output and its square yields the familiar bell-shaped relationship between the level of income and inequality. This relationship weakens once we include a measure of human capital (not reported), and entirely disappears when we control for volatility. Column 3 reports this result when we use as a measure of human capital the percentage of individuals in the total population who have attained secondary schooling (Sec85). ${ }^{1}$ Instead of a Kuznets effect, we find that the level of income has a negative and significant effect on the Gini coefficient, indicating that more developed countries have more egalitarian distributions -even before taxes.

\footnotetext{
${ }^{1}$ The volatility effect is robust to the use of other measures of education.
} 
The next two columns include other variables linked to the level of economic development. The first one is the rate of output growth. As already mentioned, Ramey and Ramey (1995) find that greater volatility is associated with lower growth. If growth then affects inequality through some sort of Kuznets mechanism, it could be the case that the coefficient on volatility is capturing an indirect relationship going from volatility to growth and from growth to inequality. Column 5 indicates that, although countries that have grown faster have, at the end of the period, a lower level of inequality, the effect of volatility on the income distribution is not mediated by the rate of growth.

The last regression equation in table 1 includes investment (as a share of GDP, averaged over the period 1960-89) as an explanatory variable. Physical capital accumulation has no impact on the Gini coefficient, in line with the results obtained by Li, Squire and Zou (1998, table 8). Educational attainment reduces inequality in all our specifications. Note that this effect is not made insignificant by the presence of LnGDP, indicating that both the level of income and the level of education affect distribution.

\subsection{Other influences on inequality}

The relationship between inequality and volatility reported in Table 1 could be caused by a common factor that affects both variables. In particular, there are differences between regions of the world - in policies, in institutions or in the structure of production- which affect both inequality and volatility. Figure 2 depicts the relationship between volatility and inequality in the various geographical regions. Countries have been divided into five groups: Africa, Latin America, the New Industrializing Countries, other Asian economies, and OECD economies. Each point in the graph represents the (unweighted) 
average volatility and average inequality for each group. Those regions with high levels of volatility also tend to exhibit high levels of inequality.

\section{Figure 2 and Table 2 around here}

Column 1 of Table 2 reports estimates obtained when we include regional dummies in our basic regression equation for the Gini coefficient. Dummies for Latin America, Asia and Africa have positive and statistically significant coefficients, but, although their presence reduces the impact of volatility on inequality, these effects nevertheless remain substantively and statistically significant. Volatility seems to be able to explain differences in inequality both across regions of the world and within those regions. The next column introduces regional dummies together with measures of the level of education and of output level. Our results are similar to those in table 1.

The impact of output volatility on inequality is not only statistically significant, but also economically significant. Consider the second equation in table 2 . For the US, an increase in volatility of one standard deviation of the distribution of volatility in our sample -up to the level of Ecuador and Malaysia- would result in an increase in the Gini coefficient of 6.4 points, which represents $64 \%$ of the standard deviation of Gini90 in our sample. An increase in volatility up to the level of Chile's (i.e. from 2.44 to 6.46) would raise the Gini coefficient in the US by one standard deviation. For Kenya, a reduction in volatility to the level experienced by the US -that is, of about two standard deviationswould reduce its Gini coefficient by 11 points, which is more than one standard deviation of Gini90.

The rest of table 2 and table 3 examine whether introducing other variables previously found to affect inequality reduces the impact of macroeconomic volatility. 
Columns 3 and 4 of table 2 consider the effect of both the agricultural structure of an economy and the degree of dualism. The regression equations are similar to those in Bourguignon and Morrisson (1998), ${ }^{2}$ except that we also include our measure of volatility and its square. The results are similar to those reported in their paper. GDP per capita and education have a weak effect, sensitive to which other variables are included. We find that cultivable land per capita has a positive impact on inequality, in contrast with the negative (though often insignificant) coefficient obtained by Bourguignon and Morrisson. In our sample, the coefficient on this variable is driven by one observation, Australia, and in fact the coefficient on land per capita becomes insignificant once it is excluded from the sample. The share of agriculture in total employment, AgEmp, has a negative and significant effect, while relative labour productivity has a positive and significant effect, indicating that the greater the extent of macroeconomic dualism, the more unequally income is distributed. Lastly, we also included in our regression equation a measure of socio-political instability (SPI), which proves to have no impact.

\section{Table 3 around here}

The regression equations reported in Table 3 include further variables based on the analysis of Li, Squire and Zou (1998): schooling measured as mean years of secondary schooling of the population in 1960, and denoted MYSch; an index of civil liberties, CIVLIB, with 1 assigned to countries with the largest degree of civil liberties and 7 to those with the smallest; and financial development, FNDP, measured by the ratio

\footnotetext{
2 We have used the share of agriculture in employment rather than in output as both in the results of Bourguignon and Morrison and in ours, the latter generally had no significant effect. We have not included two of their variables: mineral resources -which they found never to have a significant effect- and the share of small and medium farmers -as we only found data on this for a small number of countries.
} 
of either M1 or liquid liabilities to GDP averaged over $1960-1989 .{ }^{3}$ We do not include the Gini coefficient for land, as we have only found data for a small number of countries.

The first two columns in Table 3 report an equation similar to that estimated by Li, Squire and Zou (1998), except that we have not included the Gini coefficient of land amongst the regressors. Secondary schooling in 1960 has no significant effect, while the other two variables have the expected effect on inequality: fewer civil liberties -a higher value of CIVLIB- increase inequality, and more financial development reduces it. When we replace MYSch with Sec85, that is a measure of human capital at a point in time closer to our measure of inequality, all three variables have a significant effect (not reported). The next four columns include volatility as a regressor. Its effect seems robust and the coefficients are similar to those obtained in previous specifications.

The last two columns of table 3 also allow us to compare the hypotheses proposed by, on the one hand, Bourguignon and Morrisson (1998) and, on the other, Li, Squire and Zou (1998). The coefficients on civil liberties and financial development are strongly affected by the presence of other explanatory variables. In particular, adding the level of GDP per capita as a regressor renders the impact of these two variables insignificant. ${ }^{4}$ The effect of dualism and employment in agriculture seem, however, robust.

We ran further regressions to test for other of the possible effects discussed in section 2. One of them is the impact of openness on the link between volatility and inequality. We do this by adding, to our basic inequality equation, the average of the ratio of imports plus exports to GDP over the $1960-89$ period. The openness measure had no

\footnotetext{
${ }^{3}$ See the data appendix for the sources and exact definitions.

4 In their sensitivity analysis, Li, Squire and Zou (1998, table 9) include as a regressor "initial" GDP -i.e. GDP per capita in 1960- and find that the coeeficients of the variables of interest remain significant. We use current GDP, that is the level of output in 1990.
} 
significant effect and the coefficients on volatility were unaffected by its inclusion. We obtained identical results when we substituted a measure of the average ratio of exports to GDP and when we used the change in openness between 1960 and 1990.

In order to understand better the way in which volatility affects inequality we examine the impact it has on the income shares of various groups. Table 4 reports regressions of the shares of the five quintiles on volatility and other variables (data is available for only a subset of our sample). Greater volatility increases the income share of the top $20 \%$ of the population, and reduces that of all other quintiles. The effect is particularly strong on the shares of the $5^{\text {th }}, 3^{\text {rd }}$ and $2^{\text {nd }}$ quintiles, indicating that volatility results in redistribution from the middle class towards the wealthiest households. The weak impact of volatility on the $4^{\text {th }}$ quintile is probably due to the fact that we are not using an appropriate division of income groups, as volatility may increase the income share of the richest in this group (those close to the top 20\%) and reduce that of individuals close to the $3^{\text {rd }}$ quintile.

\section{Table 4 around here}

It is hard to distinguish the effect of education and the level of income. In the particular formulation reported in table 4, both a greater level of education and of income reduce the share of the top quintile. However, when the square of LnGDP90 is added to the regression equation, the coefficients on all three terms become insignificant. Dualism has a positive impact on the top quintile, a negative one on the rest, in accordance with the results obtained by Bourguignon and Morrisson (1998). We also included our measures of financial development, which were significant only in the absence of 
LnGDP. Other variables considered - such as civil liberties and land per capita - proved to have no effect on the quintile shares.

\subsection{The role of initial inequality}

In this subsection we report the results of running regressions, similar to those already described, but in which we control for the initial level of inequality. There are two reasons for doing this. First, we lack measures of some of the factors that influence inequality - such as institutional or social factors that differ between countries. To the extent that these factors change only slowly over time, they will also be a determinant of initial inequality and, consequently, we can use initial inequality as a proxy for at least some of them. Secondly, having two observations from each country provides a way of controlling, to some extent, for possible country-specific discrepancies in the way in which the data on the distribution of income were collected.

Our data set is substantially reduced when we incorporate an observation on initial inequality (i.e around 1960). Further more, there are several countries for which an observation exists for both periods, but income is measured in different ways. We therefore consider only those countries in our sample for which we have two consistent observations. This reduces the sample dramatically to 33 countries. Although small, our sample is a representative set in the sense that it incorporates countries from different regions (see table A.2, in the appendix).

Table 5 reports the estimated regression equations for the Gini coefficient. The first column presents the basic equation: volatility has the expected positive coefficient and is highly significant. We have dropped the squared-volatility term and the dummy variable for net income, and replaced them with the interaction between volatility and net 
income. $^{5}$ In this smaller sample, the coefficient on the square of volatility becomes insignificant, the reason being that we have lost all the observations with very high levels of volatility (Algeria, Bangladesh, Botswana, Gambia, Ghana, Guinea Bissau, Guyana, Iran, Jordan, Kenya, Lesotho, Mauritius, Nepal, Nicaragua, Niger, Nigeria). The interactive term provided a better fit than a model with a dummy variable for net.

\section{Table 5 around here}

In general, the results that we obtained with the larger sample are reproduced by the smaller one. The effect of volatility on inequality is not eroded by controlling for initial inequality, as its coefficient remains positive and significant. In Column 3 of the table we estimate a simple Kuznets curve and we obtain the expected inverse U-shaped relationship. However, once volatility and regional dummies are included as regressors (column 4) the coefficients on the two income variables become insignificant. The last three columns test for the effect of, on the one hand, dualism and, on the other, financial development and civil liberties. Two things are worth noting. First, that in all the specifications the coefficient on volatility remains positive, statistically significant, and economically important (an increase in volatility of one standard deviation, implies a rise in the Gini coefficient of half its standard deviation in the smaller sample). Second, that once we include initial inequality and volatility the coefficients on most other variables become insignificant.

Table 6 reports regression equations for quintile shares, which again are similar to those obtained with the larger sample, with volatility increasing the share of the top quintile and reducing that of the second and third. Given our previous results, it is

\footnotetext{
${ }^{5}$ As in the larger sample, the dummies for personal income and expenditure-based estimates prove to have insignificant coefficients.
} 
surprising to find hardly any effect of relative labour productivity. This is probably due to the fact that, since almost half of the countries in the sample are developed economies, there is not much variability in this variable (the standard deviation of this variable drops dramatically, from 3.9 in the large sample to 1.6 in the small one).

\section{Table 6 around here}

We ran the small sample models (i.e. those that include initial inequality) on a different data set consisting of only the 'high quality' observations in the Deininger and Squire dataset (these results are available on request from the authors). We found that the coefficients of most variables were generally not robust to either the specification or the data set used. By contrast, the volatility effect was consistently strong and significant.

\subsection{Alternative measures of volatility}

Using the standard deviation of growth rates as a measure of volatility is the approach generally followed by the literature on this topic. It may, however, be an unsatisfactory proxy (see Pritchett, 1998). Consider, for instance, two countries with the following growth patterns: country A has annual growth rates of $4 \%, 2 \%, 4 \%, 2 \%, 4 \%$, and $2 \%$, while country B has $4 \%, 4 \%, 4 \%, 2 \%, 2 \%$, and $2 \%$. They will have the same average rate of growth and standard deviation (3\% and 1.095, respectively) but clearly correspond to different levels of volatility. A possible way of dealing with this problem is to define higher order measures, such as the standard deviation of the first differences of the annual growth rates. This alternative measure of volatility yields a value of 2.19 for the first series, and of 0.89 for the second one, indicating that $\mathrm{A}$ is more volatile than $\mathrm{B}$.

We follow this approach and calculate the standard deviation of changes in the annual rate of growth, denoted $S D(\Delta g)$. The correlation between this measure and the 
standard deviation of the annual rate of growth is 0.95 . This seems to indicate that, in general, we are not dealing with processes such as that in country B. When we reestimate our basic regression equation using this new measure of volatility, we obtain the following equation:

$$
E\left(G_{i}\right)=21.102+6.395 S D(\Delta g)_{i}-0.315 S D(\Delta g)_{i}^{2}-6.1787 N e t
$$

( $R^{2}=0.278, S E=8.802$, standard errors in parenthesis). The results are very similar to those reported in table 1 , and the fit of the regression equation is only slightly worse than when we use our original measure. A similar equation is obtained when we use as our measure of volatility the average of the absolute values of the changes in the rate of growth, as suggested by Pritchett (1998). Substituting either of these two variables for $S D$ in other specifications of the regression equation yielded results almost identical to those previously obtained.

We also used the standard deviation of the level of GDP as an explanatory variable, and found that it has no significant effect in any of our formulations. This contrasts with the evidence discussed by Hausmann and Gavin (1996). It is, however, difficult to compare the two analyses given that they do not report either the sample or the period over which the standard deviation was calculated.

There is a second sense in which our measure of volatility may not be completely satisfactory. Fluctuations in output growth are likely to be driven by economic or social variables. In particular, we follow Ramey and Ramey (1995) and investigate the impact of government spending as a source of volatility. Let Gov be the annual rate of growth of real government expenditure, and $S D($ Gov $)$ its standard deviation over the period 196090. We regress the standard deviation of the rate of growth of output on that of the rate of 
growth of government expenditure. We can see in Table 7, column 1, that this variable is a major determinant of the volatility of output growth (as found by Ramey and Ramey, 1995). In the next two columns we add other variables to the regression equation. Sociopolitical instability is an obvious candidate to try to explain the volatility of output growth. We also test for the effect of initial inequality (measured by the Gini coefficient in 1960) on volatility. Neither of these variables has a significant effect.

\section{Table 7 around here}

The last three columns of table 7 compare the effect that the volatility of output growth and of government expenditure have on inequality in 1990. Government expenditure volatility has a positive and significant impact on inequality, but this effect disappears once we include the standard deviation of output growth, indicating that government expenditure affects inequality in so far as it makes output more volatile. We tried alternative specifications, and obtained similar results when we used as our measure of volatility the standard deviation of government expenditure as a proportion of GDP. The average rate of growth of government expenditure proved to have no significant effect.

\section{Causal Considerations}

There is a substantial literature that examines the mechanisms that relate fluctuations in the rate of growth with the mean rate of growth of output. ${ }^{6}$ However, no work has been done so far on why fluctuations may affect the distribution of income. This section proposes a possible explanation for our findings that greater volatility increases

\footnotetext{
${ }^{6}$ Examples of this are Kydland and Prescott (1982), Long and Plosser (1983), and Ramey and Ramey (1991). See Ramey and Ramey (1995) for a discussion of these models.
} 
inequality across countries. We present a simple model of an economy with workers and managers. If managers are less risk-averse than workers, the degree of riskiness of the production technology will affect the share of output obtained by each group and hence the distribution of income.

Consider an economy that consists of workers and managers. There are two differences between them. First, managers have direct access to the manufacturing production technology, while workers do not. A worker can either be employed by a manager in manufacturing, or use a backyard technology by herself. Second, they differ in their degree of risk-aversion. Workers are assumed to be more risk-averse than managers, that is, their utility function is more concave. For simplicity of exposition we will assume that managers are risk-neutral, although this is not necessary for the results. Let workers' utility be given by $U(I)$, where $I>0$ represents income. $U(I)$ is a Von Neumann Morgenstern utility function, such that the first and second derivatives with respect to income, $U_{I}$ and $U_{I I}$, exist and are continuous, and $U_{I}>0$ and $U_{I I}<0$.

One can think of this situation as the extreme version of a model in which both types of agents have the same utility function, which exhibits decreasing absolute riskaversion. Richer individuals are thus more willing to accept a certain amount of risk than poorer individuals. Hence, if managers have accumulated wealth and workers do not, the former will choose to bear more risk.

When a worker uses the backyard technology, her output at time $t$ is $z_{t}=z \cdot y_{t-1}$, where $z$ is a constant parameter. When an entrepreneur employs a worker, output is produced according to the risky technology

$$
y_{t}=\sigma_{t} y_{t-1},
$$


where $y_{t-1}$ is last period's output and $\sigma_{t}$ is the value taken by a non-degenerate random parameter. The random variable $\sigma$ is the economy-wide level of technology (it could also be interpreted as a demand parameter affecting output). Its density function is given by $f(\sigma)$, with support $\sigma \in[0, \Omega]$, where $0<\Omega<\infty$, and mean $\bar{\sigma}$.

A greater dispersion of the distribution of $\sigma$ implies that managers face greater risk. It also affects the aggregate rate of growth. Let the number of workers be normalised to one, so that the rate of growth is given by $g_{t}=y_{t} / y_{t-1}-1$ (we will show below that, in equilibrium, the backyard technology is never employed). Using equation (1), we can express it as $g_{t}=\sigma_{t}-1$. A greater dispersion of the distribution of $\sigma$ then also implies that the growth rate is more volatile over time.

The sequence of events is as follows. An entrepreneur hires workers and offers them contracts that specify their wages. The state of the world, i.e. the value of $\sigma$, is then realized, and all agents observe it. Wages are then paid. Given the timing we have just described, it is possible to make wages conditional on the realization of the shock.

For simplicity, suppose that managers may offer only two types of contracts: they could either pay workers a fraction of their random output at each point in time, or they could pay a constant wage. Suppose that when a random-wage contract is offered, workers and managers bargain over how to share output. Let $\beta$ be the (given) share received by workers and $(1-\beta)$ that received by the entrepreneur, where $\beta \in(0,1)$. We assume that $\beta \bar{\sigma}>z$, as otherwise workers would always choose to use the backyard technology. Under a random wage, the expected utility of a worker is

$$
E U\left(\beta \cdot y_{t}\right)=\int_{0}^{\Omega} U\left(\beta \cdot \sigma y_{t-1}\right) \cdot d F(\sigma)
$$


If the worker is offered a constant wage $w$, her expected utility is simply $U\left(w_{t}\right)$; while if she is not employed in manufacturing and uses the backyard technology, she obtains $U\left(z_{t}\right)$

Managers will prefer to offer a fixed-wage contract if the expected profits it generates are greater than those from a random-wage contract. That is, if

$$
E \pi\left(w_{t}\right)=\left(\bar{\sigma}_{t-1}-w_{t}\right)>E \pi\left(\beta \cdot y_{t-1}\right)=(1-\beta) \cdot \overline{\sigma y}{ }_{t} .
$$

This expression reduces to $\beta \cdot \bar{\sigma}_{t-1}>w_{t}$. From the point of view of the entrepreneur, the optimal constant wage is the lowest wage that would make a worker prefer to work under a fixed-wage than under a random-wage contract. That is, it is the wage that makes the worker indifferent between the two types of contract, subject to the constraint imposed by the outside option (the possibility of working with the backyard technology). The wage offered by the manager, $w_{t}^{*}$, is then defined by

$$
U\left(w_{t}^{*}\right)=\max \left\{E U\left(\beta \cdot y_{t}\right), U\left(z_{t}\right)\right\}
$$

Since workers are risk-averse, the certainty equivalent wage is lower than the expected random wage. That is, $\beta \cdot \overline{\sigma y}_{t-1}>w_{t}^{*} \geq z_{t}$, which implies that equation (3) always holds.

All managers will therefore offer the (bounded) certainty equivalent wage $w_{t}^{*}$, and all workers will be willing to accept it. The expected income shares of the two groups are given by

$$
S_{W}=\frac{w_{t}^{*}}{\bar{\sigma} y_{t-1}} \quad \text { and } \quad S_{E}=1-\frac{w_{t}^{*}}{\bar{\sigma} y_{t-1}}
$$

We now want to examine the effect of an increase in the volatility of output growth on the income of the two types of individuals. Consider two possible distributions 
of the random productivity level. Denote the two distributions by $R$ and $R^{\prime}$, and suppose that $R^{\prime}$ is "more risky" on the sense that it is a mean-preserving spread (MPS) of $R$. Recall that the wage is determined by $U\left(w_{t}^{*}(R)\right)=E_{R} U\left(\beta \cdot \sigma y_{t-1}\right)$, where $E_{R} U($.$) is the$ value of a worker's expected utility when the distribution of $\sigma$ is given by $R$. Because workers' utility function is concave, a mean preserving spread of the distribution of $\sigma$ reduces expected utility. That is, $E_{R} U\left(\beta \cdot \sigma y_{t-1}\right)>E_{R} U\left(\beta \cdot \sigma y_{t-1}\right)$, and hence the certainty equivalent wage is greater for the less risky distribution, $w_{t}^{*}(R)>w_{t}^{*}\left(R^{\prime}\right)$. Consequently, expected profits are greater for $R^{\prime}$ than for $R$, and the share of managers in total output, as given by equation (5) is also greater for the more risky distribution.

The intuition for this result is simple. Because managers are less risk-averse than workers, they are willing to bear more risk (under our assumption of risk-neutrality they bear all the risk). This implies that they can extract a risk premium from workers and hence increase their profits. The more risky the economy is, the greater the risk premium -i.e. the lower the wage- and the higher the income received by managers is. More volatility is hence associated with greater inequality, as it raises the income share of the top income group.

The impact of volatility on inequality is, however, bounded. As risk keeps increasing, the certainty equivalent wage falls. It will eventually reach the lower bound imposed by the backyard technology, $w_{t}^{*}\left(R^{\prime}\right)=z_{t}$. If the riskyness of $\sigma$ increases any more, entrepreneurs cannot further reduce the wage, as this would result in all workers choosing to leave manufacturing. The wage thus remains at $z_{t}$. Consequently, for very high levels of volatility, the relationship between inequality and volatility breaks down. 


\section{Conclusions}

Policy-makers are often concerned by macroeconomic volatility, and electoral programs are often full of references to "attaining economic stability". This paper has demonstrated one reason why that concern is well founded: macroeconomic volatility affects the degree of income inequality in an economy.

Our analysis of cross-country data shows that greater volatility, measured by the standard deviation of the rate of growth of output, is associated with a higher degree of inequality. This relationship is robust to controls for all the factors that previous research has shown to be determinants of income inequality. In fact, volatility, together with relative labour productivity in agriculture and the share of employment in agriculture, prove to be the most robust factors affecting income distribution. In order to understand how volatility affects the distribution of income, we have examined its impact on the income shares of the various quintiles. Greater volatility results in a redistribution from middle-income groups (second and third quintiles) to the top-income group (fifth quintile), while its effect on the share of the lowest $20 \%$ of the population is weak.

We have presented a simple model in which greater volatility is associated with a higher degree of inequality. High income individuals (managers) are characterized by a lower degree of risk-aversion than workers, and hence insure the latter. In this context, greater volatility of output, by increasing risk, shifts income from managers to workers and thus increases the degree of inequality. There are, of course, other possible mechanisms through which output fluctuations can affect distribution. For example, if education investments are characterised by fixed costs and capital markets are imperfect, the level of output will determine whether or not low-income dynasties can invest in 
education. The degree of volatility may then affect the distribution of human capital, and hence that of income. There could also be a loss of human capital if, in bad periods, those with less skills become unemployed and lose skills. Next period, the difference in skills (and hence wages) between these workers and those who remained in employment would be even greater.

A detailed examination of these mechanisms is needed if we want to fully understand the impact of volatility on inequality. However, the relationship that we have identified has in itself important implications for policy making, as it challenges the longstanding argument that distributional targets may be incompatible with efficiency goals. Policies aimed at ensuring macroeconomic stability will at the same time reduce the degree of income inequality in an economy. 


\section{References}

Aghion, P., Caroli, E. and García-Peñalosa, C. 1998: "Inequality and Economic Growth: The Perspective from the New Growth Theories", mimeo, Nuffield College.

Alesina, A. and Perotti, R. 1996: "Income Distribution, Political Instability and Investment", European Economic Review 109(2): 465-90.

Alesina, A. and Rodrik, D. 1994: "Distributive Politics and Economic Growth", Quarterly Journal of Economics 109: 465-90.

Anand, S and Kanbur, S.M.R. 1993a: "The Kuznets Process and the InequalityDevelopment Relationship", Journal of Development Economics 40(1): 25-52.

Anand, S and Kanbur, S.M.R. 1993b: "Inequality and Development: A Critique", Journal of Development Economics 41(1): 19-43.

Atkinson, A.B. 1996: "Seeking to Explain the Distribution of Income", in New Inequalities: The Changing Distribution of Income and Wealth in the United Kingdom. John Hills, ed. Cambridge: Cambridge University Press: 19-48.

Atkinson, A.B. 1997: "Bringing the Income Distribution in from the Cold", Economic Journal, 107(441): 297-321.

Barro, R.J. and Lee, J.-W. 1993: "International Comparisons of Educational Attainment", Journal of Monetary Economics, 32 (3): 363-94.

Bourguignon, F. and Morrisson, C. 1990. "Income distribution, development and foreign trade: a cross-section analysis", European Economic Review, 34 (): 1113-32.

Bourguignon, F. and Morrisson, C. 1998. "Inequality and development and: the role of dualism", Journal of Development Economics, 57 (): 233-57.

Chen, S., Datt G. and Ravaillon, M. 1994. "Is Poverty increasing in the Developing World?", Review of Income and Wealth, 40 (4): 359-76.

Deininger, K. and Squire, L. 1996: "Measuring income inequality: a new data base", The World Bank Economic Review 10 (3): 565-591.

FAO. 1992. Production yearbook, Food and Agriculture Organization, Rome.

Fiszbein, Ariel and George Psacharopoulos. 1995. "Income Inequality Trends in Latin America", in Nora Lustig, ed. Coping with Austerity: Poverty and Inequality in Latin America, The Brookings Institution, Washington.

Gastil, R. Freedom in the World, Westport: Greenwood. 
Gottschalk, Peter and Timothy M. Smeeding 1997 'Cross-National Comparisons of

Earnings and Income Inequality' Journal of Economic Literature, 35: 633-687.

Hausmann, R., and Gavin, M. 1996: "Securing Stability and Growth in a Shock Prone Region: The Policy Challenges for Latin America", in Hausmann, R. and Reisen, H. (eds.) Securing Stability and Growth in Latin America, OECD Paris.

King, R.G. and Levine, R. 1993: "Finance, Managership, and Growth: Theory and Evidence", Journal of Monetary Economics 32 (3): 513-42..

Kuznets, S. 1955: "Economic Growth and Income Inequality", American Economic Review 45 (1): 1-28.

Kuznets, Simon. 1963. "Quantitative Aspects of the Economic Growth of Nations", Economic Development and Cultural Change, 11(2): 1-80.

Levine, R. and Renelt, D. 1992: “A Sensitivity Analysis of Cross-Country Growth Models" American Economic Review 82: 942-63.

Li, H., Squire, L. and Zou, H.-F. 1998: "Explaining International and Intertemporal Variations in Income Inequality”, Economic Journal 108: 26-43.

Kihlstrom, R.E. and Laffont, J.-J. 1979: “A General Equilibrium Entrepreneurial Theory of Firm Formation Based on Risk Aversion", Journal of Political Economy 87(4): 719-748.

Kuznets, S. 1955: "Economic Growth and Income Inequality", American Economic Review, 45: 1-28.

Kydland, F.E. and Prescott, E.C. 1982: "Time to Build and Aggregate Fluctuations", Econometrica, 50(6): 1345-70.

Long, J.B. and Plosser, C.I. 1983: "Real Business Cycles", Journal of Political Economy, 91(1): 39-69.

Perotti, R. 1996: "Growth, Income Distribution and Democracy: What the Data Say", Journal of Economic Growth, 1: 149-187.

Pritchett, L. 1998. "Patterns of Economic Growth: Hills, Plateaus, Mountains, and Plains", miemo, World Bank.

Ramey, G. and Ramey, V.A. 1995: "Cross-Country Evidence on the Link Between Volatility and Growth", American Economic Review, 85(5): 1138-1151. 
Ramey, G. and Ramey, V.A. 1991: "Technology Commitment and the Cost of Economic Fluctuations", NBER Working Paper: 3755.

Summers, and Heston : "Penn World Tables, Mark 5.6".

World Bank. 1993. World Tables.

World Bank. 1996: World Development Report. 


\section{Appendix: Data Sources and Main Data}

\section{A.1. Inequality}

Almost all the data on inequality is from Deininger and Squire (1996), obtained from the World Bank Webb Site (version 13/6/97). We first selected all the observations that were obtained from surveys of national coverage, for the years of interest (or as close as possible, ranging between 1984 and 1995). This implied that for many countries there were several observations for the same year, in some cases giving rather different values. For the OECD we chose the observations recommended by Atkinson and Brandolini (1999). This means that we have, in most cases, used the LIS data. For Italy in 1991 we have used the data available in the LIS Webb site, following the suggestion of Atkinson and Brandolini. For developing countries, we have mainly used the data from Chen, Datt and Ravaillon (1994) and the World Development Report, as reported by Deininger and Squire. When, exceptionally, the data from these two sources differed, we have computed an average value (this was the case for Tanzania, Zambia and Venezuela). Whenever possible, we have used observations of the distribution of income rather than expenditure. For this reason, the observation we have used for Bangladesh is that for 1986, rather than those for 1989 and 1990. We also selected observations that reported the distribution of gross (rather than net) and personal or person equivalent (rather than household) income. This was not always possible.

GINIxx: Gini coefficient of income in or around the year 19xx.

Qy,xx: Income share of the $y^{\text {th }}$ quintile in or around the year 19xx.

Net: Dummy variable taking the value 1 if the inequality measure is based on net income, and 0 if it is based on gross income. 


\section{A.2. Output and volatility}

LnGDPXX: Logarithm of real per capita GDP in the year 19XX. The output variable used is real GDP per capita in 1985 constant dollars (Chain Index).

SD: Standard deviation of the rate of output growth. Output is real per capita GDP. We calculate the annual rate of growth of over the period 1960 to 1990 , and then the standard deviation of annual growth rates.

Growth60-90: Average annual rate of growth of real per capita GDP over 1960 to 1990.

$\operatorname{SD}(\Delta \mathrm{g})$ : Standard deviation of the year to year changes in the annual rate of output growth, over the period 1960 to 1990.

Gov: Annual rate of growth of real government expenditure (1985 prices). Obtained by multiplying the real government share of GDP by real per capita GDP.

$\mathrm{SD}$ (Gov): Standard deviation of the annual rate of growth of real government expenditure over the period 1960-90.

Source: Summers and Heston, Penn World Tables Mark 5.6.

\section{A.3. Education}

Sec85: Percentage of "secondary schooling attained" in the total population in 1985.

MYSch: mean years of secondary schooling in the total population in 1960.

Source: Barro and Lee (1993).

\section{A.4. Agriculture}

AgEmp: Percentage of the economically active population employed in agriculture.

Land pc: Arable land and land under permanent crops in 1991 (in $1000 \mathrm{Ha}$ ) divided by the total population in 1990 (in 1000s).

Source: FAO Production yearbook, 1992, Tables 1 and 3. 
AgShare: Agricultural output as a share of GDP. Three years averages (for 1988, 1989, and 1990) are used in order to smooth possible fluctuations in agricultural prices. For some countries the data are for $1987-89$, for Peru it is for $1978-80$.

Source: World Bank World Tables 1993.

RLP: Relative labour productivity (non-agriculture/agriculture). Calculated as $R L P=(1-$ AgShare)AgEmp/((1-AgEmp)AgShare).

\section{A.5. Other variables}

CIVLIB: Index of civil liberties, averaged over 1960-89. A value of 1 is assigned to countries with the largest degree of civil liberties, and 7 to those with the smallest.

FNDV (M1Y): Degree of financial development, measured by the ratio of M1 to GDP averaged over 1960-1989.

FNDV (LLY): Degree of financial development, measured by the ratio of liquid liabilities to GDP averaged over 1960-1989.

INV: Investment share in GDP, averaged over the period 1960-89.

TRD: Ratio of total trade (imports plus exports) to GDP, averaged over 1960-89.

X: export share of GDP, averaged over the period 1960-89.

TRDG: Growth of the ratio of total trade to GDP between 1960 and 1990.

Source of all the above: King and Levine (1993). The names of the variables in the original data set are, respectively, CIVL, LLY, INV, TRD, X, TRDG.

SPI: Index of socio-political instability over the period 1960-85, where a higher value indicates more instability. From Alesina and Perotti (1996) 
Table A.1: Main Data for the 80-Country Sample

\begin{tabular}{|c|c|c|c|c|c|}
\hline Country & Gini & SD & Country & Gini & SD \\
\hline Algeria & 38.73 & 7.553 & Korea, R. & 33.64 & 4.097 \\
\hline Australia & 35.93 & 2.698 & Lesotho & 60.90 & 7.443 \\
\hline Austria & 31.60 & 1.74 & Luxembourg & 23.81 & 4.203 \\
\hline Bangladesh & 37.00 & 8.961 & Madagascar & 43.44 & 4.229 \\
\hline Belgium & 29.24 & 2.218 & Malawi & 62.00 & 5.043 \\
\hline Bolivia & 42.04 & 3.473 & Malaysia & 48.35 & 4.926 \\
\hline Botswana & 54.21 & 8.582 & Mali & 54.00 & 5.371 \\
\hline Brazil & 63.42 & 4.624 & Mauritania & 42.53 & 6.820 \\
\hline Burkina Faso & 39.00 & 4.703 & Mauritius & 36.69 & 8.308 \\
\hline C. Afr. Rep. & 55.00 & 4.171 & Mexico & 54.98 & 4.220 \\
\hline Canada & 32.73 & 2.486 & Morocco & 39.20 & 5.514 \\
\hline Chile & 56.49 & 6.458 & Nepal & 30.06 & 7.460 \\
\hline Colombia & 51.32 & 2.448 & Netherlands & 29.10 & 2.139 \\
\hline Costa Rica & 46.07 & 3.739 & New Zealand & 36.58 & 2.957 \\
\hline Cote d'Ivoire & 38.00 & 6.562 & Nicaragua & 50.32 & 9.268 \\
\hline Denmark & 28.75 & 2.726 & Niger & 36.10 & 9.841 \\
\hline Dom. Rep. & 50.46 & 6.843 & Nigeria & 41.15 & 11.160 \\
\hline Ecuador & 43.00 & 4.774 & Norway & 27.29 & 1.900 \\
\hline Egypt & 32.00 & 3.362 & Pakistan & 32.38 & 4.231 \\
\hline Finland & 26.31 & 3.000 & Panama & 56.47 & 5.726 \\
\hline France & 33.52 & 1.879 & Peru & 44.87 & 6.598 \\
\hline Gambia & 39.00 & 9.760 & Philippines & 45.73 & 3.585 \\
\hline Germany & 26.00 & 2.250 & Portugal & 36.76 & 4.364 \\
\hline Ghana & 36.74 & 7.069 & Puerto Rico & 50.86 & 3.672 \\
\hline Greece & 37.67 & 3.732 & Senegal & 54.12 & 4.274 \\
\hline Guatemala & 59.06 & 3.071 & Singapore & 41.00 & 4.802 \\
\hline Guinea & 40.40 & 6.411 & South Africa & 62.30 & 3.689 \\
\hline Guin. Bissau & 56.12 & 9.455 & Spain & 25.91 & 3.253 \\
\hline Guyana & 40.22 & 11.773 & Sri Lanka & 46.70 & 4.643 \\
\hline Honduras & 52.63 & 2.978 & Sweden & 26.31 & 1.760 \\
\hline Hong Kong & 45.00 & 4.020 & Taiwan & 30.53 & 2.805 \\
\hline India & 32.53 & 5.029 & Tanzania & 48.56 & 6.046 \\
\hline Indonesia & 33.09 & 3.960 & Thailand & 50.80 & 3.408 \\
\hline Iran & 42.90 & 9.468 & Tunisia & 40.24 & 3.362 \\
\hline Ireland & 37.90 & 2.580 & Turkey & 44.09 & 3.536 \\
\hline Italy & 29.00 & 2.667 & UK & 34.32 & 2.198 \\
\hline Jamaica & 41.79 & 4.917 & USA & 38.51 & 2.439 \\
\hline Japan & 35.00 & 3.526 & Venezuela & 48.96 & 4.276 \\
\hline Jordan & 40.66 & 10.118 & Zambia & 47.46 & 6.509 \\
\hline \multirow[t]{2}{*}{ Kenya } & 54.39 & 7.681 & Zimbabwe & 56.83 & 5.731 \\
\hline & & & Average & 41.98 & 4.99 \\
\hline
\end{tabular}


Table A.2: Main Data for the 33-Country Sample

\begin{tabular}{lrrrrrr}
\hline Country & Gini90 & Gini60 & Q5,90 & Q5,60 & \multicolumn{2}{c}{ SD Net } \\
\hline Australia & 35.93 & 32.00 & 0.42 & 0.39 & 2.70 & 0 \\
Brazil & 63.42 & 54.00 & 0.67 & 0.62 & 4.62 & 0 \\
Canada & 32.73 & 30.80 & 0.39 & 0.35 & 2.49 & 0 \\
Colombia & 51.32 & 62.00 & 0.54 & 0.68 & 2.45 & 0 \\
Costa Rica & 46.07 & 50.00 & 0.51 & 0.60 & 3.74 & 0 \\
Denmark & 28.75 & 37.00 & 0.36 & 0.41 & 2.73 & 0 \\
Finland & 26.31 & 46.00 & 0.35 & 0.49 & 3.00 & 0 \\
France & 33.52 & 50.00 & 0.41 & 0.54 & 1.88 & 0 \\
Hong Kong & 45.00 & 46.20 & 0.49 & 0.57 & 4.02 & 0 \\
India & 32.53 & 32.59 & 0.42 & 0.41 & 5.03 & 1 \\
Indonesia & 33.09 & 33.30 & 0.42 & n.a. & 3.96 & 1 \\
Japan & 35.00 & 37.20 & n.a. & 0.44 & 3.53 & 0 \\
Korea, R. & 33.64 & 34.34 & 0.42 & 0.42 & 4.10 & 0 \\
Malaysia & 48.35 & 36.00 & 0.54 & 0.44 & 4.93 & 0 \\
Mexico & 54.98 & 53.00 & 0.59 & 0.60 & 4.22 & 0 \\
Netherlands & 29.10 & 42.00 & 0.37 & 0.48 & 2.14 & 0 \\
New Zealand & 36.58 & 35.70 & 0.42 & n.a. & 2.96 & 0 \\
Norway & 27.29 & 35.00 & 0.36 & 0.41 & 1.90 & 0 \\
Pakistan & 32.38 & 34.70 & 0.35 & n.a. & 4.23 & 0 \\
Panama & 56.47 & 50.02 & 0.60 & n.a. & 5.73 & 0 \\
Philippines & 45.73 & 48.00 & 0.53 & 0.56 & 3.58 & 0 \\
Puerto Rico & 50.86 & 52.32 & 0.53 & 0.54 & 3.67 & 0 \\
South Africa & 62.30 & 55.00 & 0.65 & n.a. & 3.69 & 0 \\
Sri Lanka & 46.70 & 47.00 & 0.52 & 0.52 & 4.64 & 0 \\
Sweden & 26.31 & 35.74 & 0.35 & 0.40 & 1.76 & 0 \\
Taiwan & 30.53 & 32.24 & 0.39 & 0.41 & 2.81 & 0 \\
Tanzania & 48.56 & 39.00 & 0.54 & n.a. & 6.05 & 1 \\
Thailand & 50.80 & 41.28 & n.a. & 0.50 & 3.41 & 0 \\
Tunisia & 40.24 & 42.30 & 0.46 & 0.49 & 3.36 & 1 \\
Turkey & 44.09 & 56.00 & 0.50 & 0.60 & 3.54 & 0 \\
UK & 34.32 & 29.68 & 0.41 & 0.38 & 2.20 & 0 \\
USA & 38.51 & 35.69 & 0.43 & 0.41 & 2.44 & 0 \\
Venezuela & 48.96 & 42.00 & 0.54 & 0.48 & 4.28 & 0 \\
\hline Average & $\mathbf{4 0 . 9 2}$ & $\mathbf{4 2 . 0 6}$ & $\mathbf{0 . 4 7}$ & $\mathbf{0 . 4 9}$ & $\mathbf{3 . 5 1}$ & \\
\hline & & & & & &
\end{tabular}


Figure 1:

Volatility and the Gini Coefficient

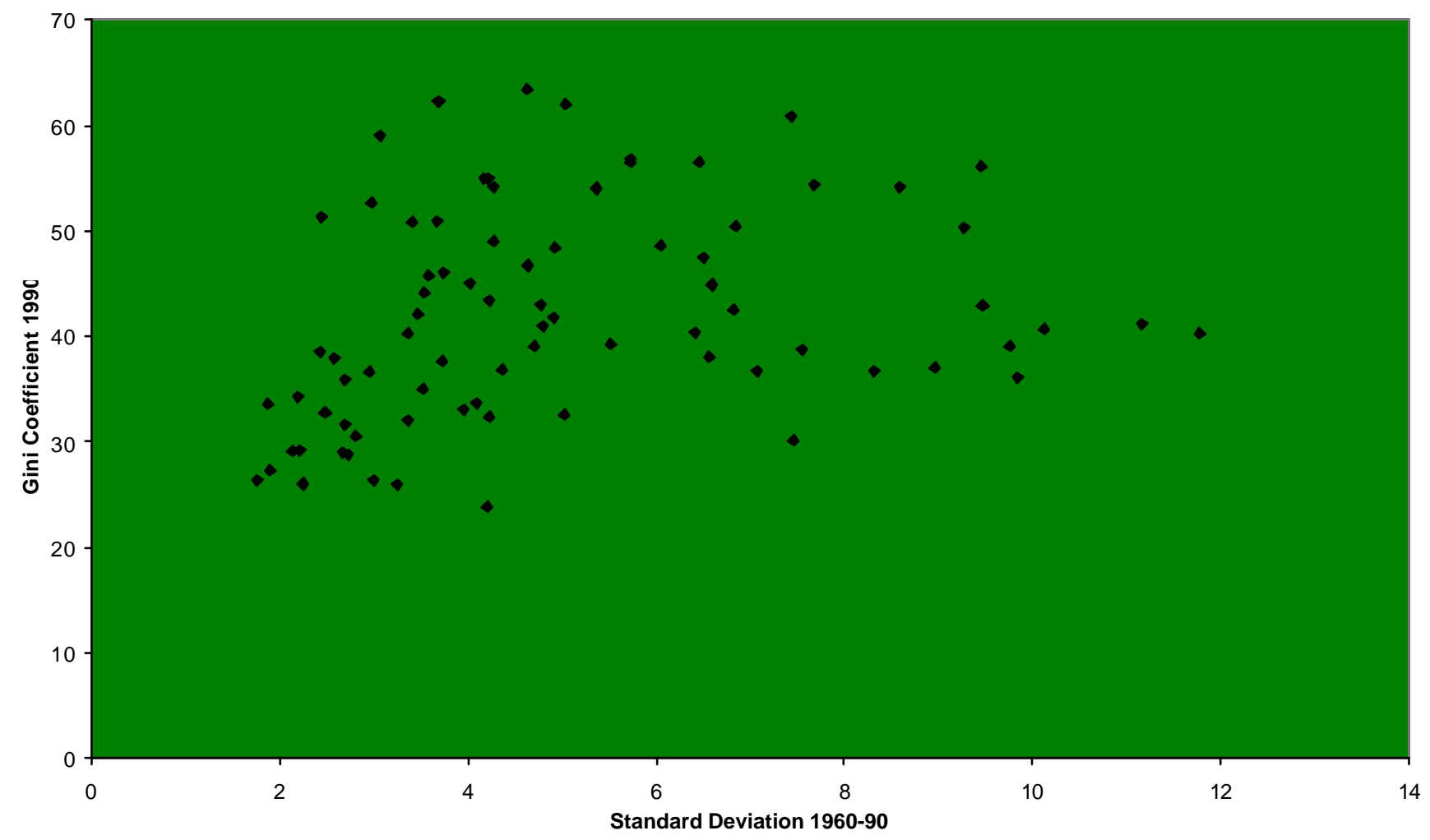


Figure 2:

Volatility and the Gini Coefficient by Region

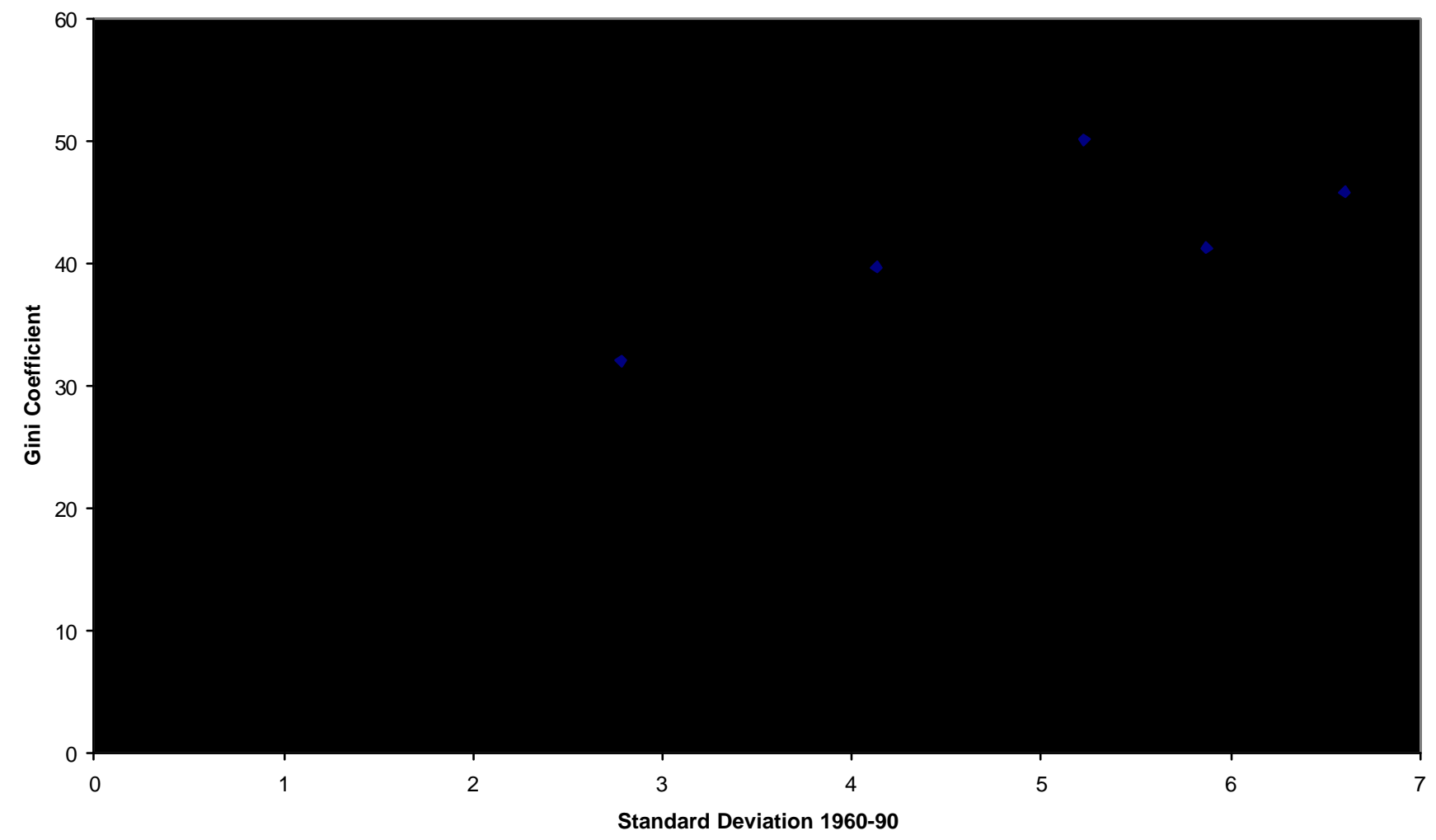


Table 1: Gini Coefficient Analysis

\begin{tabular}{|c|c|c|c|c|c|c|}
\hline & Gini90 & Gini90 & Gini90 & Gini90 & Gini90 & Gini90 \\
\hline Constant & $\begin{array}{c}16.033 * * * \\
(3.694)\end{array}$ & $\begin{array}{c}-43.258 \\
(54.782)\end{array}$ & $\begin{array}{c}13.927 \\
(57.068)\end{array}$ & $\begin{array}{c}66.888 * * * \\
(13.197)\end{array}$ & $\begin{array}{c}34.775 * * * \\
(5.136)\end{array}$ & $\begin{array}{c}32.094 * * * \\
(6.568)\end{array}$ \\
\hline $\begin{array}{l}\text { SD } \\
\text { SD }^{2}\end{array}$ & $\begin{array}{c}10.067 * * * \\
(1.470) \\
-0.680 * * * \\
(0.112)\end{array}$ & & $\begin{array}{c}5.171 * * * \\
(1.593) \\
-0.407 * * * \\
(0.116)\end{array}$ & $\begin{array}{c}5.833 * * * \\
(1.553) \\
-0.453 * * * \\
(0.117)\end{array}$ & $\begin{array}{c}8.020 * * * \\
(1.477) \\
-0.611 * * * \\
(0.122)\end{array}$ & $\begin{array}{c}7.846 * * * \\
(1.621) \\
-0.577 * * * \\
(0.114)\end{array}$ \\
\hline $\begin{array}{l}\text { Net } \\
\text { LnGPD90 } \\
\text { (LnGPD90) }^{2}\end{array}$ & $\begin{array}{c}-6.320 * * * \\
(2.367)\end{array}$ & $\begin{array}{c}-7.917 * * * \\
(2.106) \\
29.322 * * \\
(13.538) \\
-2.220 * * * \\
(0.827)\end{array}$ & $\begin{array}{c}-8.213 * * * \\
(2.585) \\
10.188 \\
(14.655) \\
-0.892 \\
(0.919)\end{array}$ & $\begin{array}{c}-8.757 * * * \\
(2.602) \\
-3.845 * * * \\
(1.343)\end{array}$ & $\begin{array}{c}-8.586 * * * \\
(2.513)\end{array}$ & $\begin{array}{c}-7.853 * * * \\
(2.634)\end{array}$ \\
\hline $\begin{array}{l}\text { Sec85 } \\
\text { Growth60-90 } \\
\text { Investment }\end{array}$ & & & $\begin{array}{c}-0.162 * * \\
(0.075)\end{array}$ & $\begin{array}{c}-0.187 * * * \\
(0.074)\end{array}$ & $\begin{array}{c}-0.282 * * * \\
(0.071) \\
-1.438 * * * \\
(0.536)\end{array}$ & $\begin{array}{c}-0.323 * * * \\
(0.080)\end{array}$ \\
\hline $\mathrm{N}$ & 80 & 80 & 70 & 70 & 70 & 68 \\
\hline$R^{2}$ & 0.291 & 0.413 & 0.505 & 0.498 & 0.495 & 0.463 \\
\hline Adjusted $R^{2}$ & 0.273 & 0.398 & 0.466 & 0.467 & 0.464 & 0.429 \\
\hline Standard Error & 8.671 & 7.886 & 7.677 & 7.665 & 7.686 & 7.892 \\
\hline
\end{tabular}

Note: Standard errors in parentheses.

* significant at the $10 \%$ level

** significant at the $5 \%$ level

$* * *$ significant at the $1 \%$ level

Due to data availability, we have removed Burkina Faso, Cote d'Ivoire, Egypt, Guinea, Luxembourg, Madagascar, Mauritania, Morocco, Nigeria, and Puerto Rico from the last four regression equations. For the last one, we have also removed Nepal and Taiwan. 
Table 2: Regional Dummies and Dualism

\begin{tabular}{|c|c|c|c|c|}
\hline & Gini90 & Gini90 & Gini90 & Gini90 \\
\hline Constant & $\begin{array}{c}25.247 * * * \\
(3.384)\end{array}$ & $\begin{array}{c}-0.947 \\
(75.742)\end{array}$ & $\begin{array}{c}117.752 * \\
(69.541)\end{array}$ & $\begin{array}{l}56.460 \\
(104.4)\end{array}$ \\
\hline SD & $\begin{array}{c}4.271 * * * \\
(1.621)\end{array}$ & $\begin{array}{c}3.788 * * \\
(1.650)\end{array}$ & $\begin{array}{c}5.252 * * * \\
(1.467)\end{array}$ & $\begin{array}{c}7.728 * * * \\
(2.399)\end{array}$ \\
\hline $\mathrm{SD}^{2}$ & $\begin{array}{c}-0.316 \text { *** } \\
(0.109)\end{array}$ & $\begin{array}{c}-0.312 * * * \\
(0.121)\end{array}$ & $\begin{array}{c}-0.450 * * * \\
(0.115)\end{array}$ & $\begin{array}{c}-0.665 * * * \\
(0.221)\end{array}$ \\
\hline Net & $\begin{array}{c}-8.181 \text { *** } \\
(1.899)\end{array}$ & $\begin{array}{c}-8.859 * * * \\
(2.143)\end{array}$ & $\begin{array}{c}-10.040 \text { **** } \\
(2.443)\end{array}$ & $\begin{array}{c}-8.733 * * * \\
(3.063)\end{array}$ \\
\hline LnGDP90 & & $\begin{array}{c}10.264 \\
(19.037)\end{array}$ & $\begin{array}{l}-7.117 \\
(15.884)\end{array}$ & $\begin{array}{c}4.123 \\
(23.939)\end{array}$ \\
\hline$(\operatorname{LnGPD90})^{2}$ & & $\begin{array}{l}-0.726 \\
(1.177)\end{array}$ & $\begin{array}{l}-0.220 \\
(0.932)\end{array}$ & $\begin{array}{l}-0.802 \\
(1.402)\end{array}$ \\
\hline Sec85 & & $\begin{array}{c}-0.116 * \\
(0.069)\end{array}$ & $\begin{array}{c}-0.159 * * \\
(0.075)\end{array}$ & $\begin{array}{c}-0.093 \\
(0.076)\end{array}$ \\
\hline Latin & $15.863 * * *$ & $10.997 * * *$ & & \\
\hline Africa & $\begin{array}{c}(2.347 * * * \\
(3.274)\end{array}$ & $\begin{array}{c}13.482 * * * \\
(5.064)\end{array}$ & & \\
\hline Asia & $\begin{array}{c}7.529 * * \\
(3.683)\end{array}$ & $\begin{array}{c}2.663 \\
(4.825)\end{array}$ & & \\
\hline NIC & $\begin{array}{c}2.392 \\
(3.403)\end{array}$ & $\begin{array}{c}0.975 \\
(3.654)\end{array}$ & & \\
\hline Land pc & & & $\begin{array}{l}1.607 * \\
(0.887)\end{array}$ & \\
\hline AgEmp & & & $\begin{array}{c}-0.309 * * * \\
(0111)\end{array}$ & $\begin{array}{c}-0.268 * * \\
(0135)\end{array}$ \\
\hline RLP & & & $0.972 * * *$ & $0.987 * * *$ \\
\hline & & & $(0.302)$ & $(0.319)$ \\
\hline SPI & & & & $\begin{array}{r}-0.0503 \\
(0.101)\end{array}$ \\
\hline $\mathrm{N}$ & 80 & 70 & 69 & 50 \\
\hline$R^{2}$ & 0.559 & 0.629 & 0.601 & 0.665 \\
\hline Adjusted $R^{2}$ & 0.523 & 0.573 & 0.548 & 0.600 \\
\hline Standard Error & 7.027 & 6.861 & 7.049 & 6.827 \\
\hline
\end{tabular}

Note: Standard errors in parentheses.

* significant at the $10 \%$ level

** significant at the $5 \%$ level

$* * *$ significant at the $1 \%$ level

For all but the first regression, we have removed Burkina Faso, Cote d'Ivoire, Egypt, Guinea, Luxembourg, Madagascar, Mauritania, Morocco, Nigeria, and Puerto Rico, due to data availability. For regression 3 we have also removed Taiwan. For the last regression we have also removed Algeria, Belgium, Central African Republic, Gambia, Ghana, Guatemala, Guinea Bissau, Guyana, Hong Kong, Indonesia, Jordan, Korea, Lesotho, Mali, Mauritius, Nepal, Nicaragua, Portugal, Singapore and Taiwan. 
Table 3: Financial Development and Civil Liberties

\begin{tabular}{|c|c|c|c|c|c|c|}
\hline & Gini90 & Gini90 & Gini90 & Gini90 & Gini90 & Gini90 \\
\hline Constant & $\begin{array}{l}37.925 * * * \\
(3.820)\end{array}$ & $\begin{array}{c}37.945 * * * \\
(4.451)\end{array}$ & $\begin{array}{c}38.190 \text { **** } \\
(5.732)\end{array}$ & $\begin{array}{c}35.164 \text { **** } \\
(6.059)\end{array}$ & $\begin{array}{c}92.904 \\
(70.658)\end{array}$ & $\begin{array}{c}91.604 \\
(71.567)\end{array}$ \\
\hline SD & & & $\begin{array}{c}4.177 * * \\
(1.702)\end{array}$ & $\begin{array}{c}4.921 * * * \\
(1.758)\end{array}$ & $\begin{array}{c}3.681 * * \\
(1.703)\end{array}$ & $\begin{array}{c}4.106 * * \\
(1.699)\end{array}$ \\
\hline $\mathbf{S D}^{2}$ & & & $\begin{array}{c}-0.336 * * * \\
(0.126)\end{array}$ & $\begin{array}{c}-0.388 * * * \\
0.135\end{array}$ & $\begin{array}{c}-0.345 * * * \\
(0.126)\end{array}$ & $\begin{array}{c}-0.379 * * * \\
(0.124)\end{array}$ \\
\hline Net & & & $\begin{array}{c}-7.023 * * \\
(2.758)\end{array}$ & $\begin{array}{c}-7.874 * * * \\
(2.622)\end{array}$ & $\begin{array}{c}-8.617 * * * \\
(2.864)\end{array}$ & $\begin{array}{c}-9.334 * * * \\
(2.573)\end{array}$ \\
\hline MYSch & $\begin{array}{c}0.618 \\
(1.558)\end{array}$ & $\begin{array}{c}1.025 \\
(1.759)\end{array}$ & & & & \\
\hline LnGDP90 & & & & & $\begin{array}{l}-1.6577 \\
(16.735)\end{array}$ & $\begin{array}{c}-1.146 \\
(16.836)\end{array}$ \\
\hline$\left(\right.$ LnGPD90) ${ }^{2}$ & & & & & $\begin{array}{c}0.461 \\
(1.007)\end{array}$ & $\begin{array}{l}-0.553 \\
(1.013)\end{array}$ \\
\hline Sec85 & & & $\begin{array}{c}-0.243 * * * \\
(0.080)\end{array}$ & $\begin{array}{c}-0.214 * * * \\
(0.080)\end{array}$ & $\begin{array}{c}-0.156 * * \\
(0.078)\end{array}$ & $\begin{array}{l}-0.118 \\
(0.076)\end{array}$ \\
\hline CIVLIB & $\begin{array}{c}2.830 * * * \\
(0.734)\end{array}$ & $\begin{array}{c}2.463 * * * \\
(0.749)\end{array}$ & $\begin{array}{l}1.584 * \\
(0.841)\end{array}$ & $\begin{array}{l}1.523 * \\
(0.875)\end{array}$ & $\begin{array}{c}0.844 \\
(0.746)\end{array}$ & $\begin{array}{c}0.719 \\
(0.730)\end{array}$ \\
\hline FNDV (M1Y) & $\begin{array}{c}-34.118 * * * \\
(9.508)\end{array}$ & ( & $\begin{array}{c}-19.139 * \\
(9.833)\end{array}$ & & $\begin{array}{l}-13.804 \\
(12.793)\end{array}$ & \\
\hline FNDV (LLY) & & $\begin{array}{c}-13.625 * * \\
(5.578)\end{array}$ & & $\begin{array}{l}-6.567 \\
(4.366)\end{array}$ & & $\begin{array}{l}-1.037 \\
(5.556)\end{array}$ \\
\hline AgEmp & & & & & $\begin{array}{c}-0.306 * * * \\
(0.108)\end{array}$ & $\begin{array}{c}-0.307 * * * \\
(0.108)\end{array}$ \\
\hline RLP & & & & & $\begin{array}{c}0.991 * * \\
(0.504)\end{array}$ & $\begin{array}{l}1.007 * * \\
(0.498)\end{array}$ \\
\hline $\mathrm{N}$ & 62 & 63 & 61 & 62 & 61 & 62 \\
\hline$R^{2}$ & 0.352 & 0.344 & 0.521 & 0.520 & 0.615 & 0.622 \\
\hline Adjusted $R^{2}$ & 0.330 & 0.322 & 0.477 & 0.477 & 0.564 & 0.573 \\
\hline Standard Error & 8.142 & 8.309 & 7.197 & 7.302 & 6.709 & 6.733 \\
\hline
\end{tabular}

Note: Standard errors in parentheses.

$$
\begin{aligned}
& * \quad \text { significant at the } 10 \% \text { level } \\
& * * \text { significant at the } 5 \% \text { level } \\
& * * * \text { significant at the } 1 \% \text { level }
\end{aligned}
$$

For all regressions, we have removed Botswana, Burkina Faso, Cote d'Ivoire, Guinea, Guyana, Hong Kong, Lesotho, Luxembourg, Madagascar, Mauritania, Morocco, Nepal, Nigeria, Puerto Rico, Taiwan, and Zimbabwe, due to data availability. For regression 1 we have also removed Chile and Sweden; for regression 2, Mexico; for regressions 3 and 5, Chile, Egypt and Sweden; for regressions 4 and 6, Egypt and Mexico. 
Table 4: Quintile Analysis

\begin{tabular}{|l|c|c|c|c|c|}
\hline & $\mathbf{Q 5 , 9 0}$ & $\mathbf{Q 4 , 9 0}$ & $\mathbf{Q 3 , 9 0}$ & $\mathbf{Q 2 , 9 0}$ & $\mathbf{Q 1 , 9 0}$ \\
\hline Constant & $124.923 * * *$ & 5.637 & -6.563 & -12.802 & $-11.188 *$ \\
& $(26.056)$ & $(6.707)$ & $(7.249)$ & $(8.659)$ & $(6.622)$ \\
SD & $4.189 * * *$ & $-0.773 * *$ & $-1.539 * * *$ & $-1.592 * * *$ & $-0.905 * *$ \\
& $(1.223)$ & $(0.324)$ & $(0.334)$ & $(0.397)$ & $(0.357)$ \\
SD & $-0.388 * * *$ & $0.057 * *$ & $0.124 * * *$ & $0.131 * * *$ & $0.076 * *$ \\
& $(0.100)$ & $(0.026)$ & $(0.027)$ & $(0.033)$ & $(0.030)$ \\
Net & $-9.318 * * *$ & $2.240 * * *$ & $2.525 * * *$ & $2.342 * * *$ & $2.211 * * *$ \\
& $(2.237)$ & $(0.880)$ & $(0.616)$ & $(0.740)$ & $(0.557)$ \\
LnGPD90 & $-9.262 * * *$ & $1.898 * * *$ & $2.588 * * *$ & $2.822 * * *$ & 1.954 \\
& $(2.745)$ & $(0.719)$ & $(0.774)$ & $(0.915)$ & $(0.705)$ \\
Sec85 & $-0.124 *$ & 0.027 & $0.042 * *$ & 0.030 & 0.024 \\
& $(0.068)$ & $(0.019)$ & $(0.020)$ & $(0.022)$ & $(0.018)$ \\
AgEmp & $-0.286 * * *$ & $0.043 * *$ & $0.082 * * *$ & $0.093 * * *$ & $0.067 * *$ \\
& $(0.096)$ & $(0.019)$ & $(0.026)$ & $(0.032)$ & $(0.028)$ \\
RLP & $0.920 * * *$ & $-0.187 * * *$ & $-0.267 * * *$ & $-0.275 * * *$ & $-0.189 * * *$ \\
& $(0.230)$ & $(0.062)$ & $(0.067)$ & $(0.073)$ & $(0.064)$ \\
\hline N & 59 & 59 & 59 & 59 & 59 \\
$R^{2}$ & 0.586 & 0.498 & 0.626 & 0.515 & 0.418 \\
Adjusted $R^{2}$ & 0.538 & 0.440 & 0.583 & 0.459 & 0.351 \\
St. Error & 6.164 & 1.772 & 1.700 & 2.022 & 1.645 \\
\hline
\end{tabular}

Note: Standard errors in parentheses.

* significant at the $10 \%$ level

$* *$ significant at the $5 \%$ level

*** significant at the $1 \%$ level

For all these regressions, we have removed Burkina Faso, Central African Rep., Cote d'Ivoire, Egypt, Gambia, Germany, Guinea, Iran, Japan, Lesotho, Luxembourg, Madagascar, Malawi, Mali, Mauritania, Morocco, Nigeria, Puerto Rico, Taiwan, Thailand, and Zambia, due to data availability. 
Table 5: Gini Coefficient Analysis

\begin{tabular}{|c|c|c|c|c|c|c|c|}
\hline & Gini90 & Gini90 & Gini90 & Gini90 & Gini90 & Gini90 & Gini90 \\
\hline Constant & $\begin{array}{c}17.556 * * * \\
(3.864)\end{array}$ & $\begin{array}{l}-5.011 \\
(5.411)\end{array}$ & $\begin{array}{c}-238.966 \\
(157.86)\end{array}$ & $\begin{array}{l}-50.210 \\
(121.86)\end{array}$ & $\begin{array}{c}79.109 \\
(180.14)\end{array}$ & $\begin{array}{c}7.641 \\
(8.867)\end{array}$ & $\begin{array}{c}-2.216 \\
(12.776)\end{array}$ \\
\hline Gini60 & & $\begin{array}{c}0.668 * * * \\
(0.129)\end{array}$ & & $\begin{array}{c}0.495 * * \\
(0.210)\end{array}$ & $\begin{array}{c}0.550 * * \\
(0.244)\end{array}$ & $\begin{array}{c}0.648 * * * \\
(0.172)\end{array}$ & $\begin{array}{c}0.604 * * * \\
(0.214)\end{array}$ \\
\hline SD & $\begin{array}{c}7.067 * * * \\
(1.178)\end{array}$ & $\begin{array}{c}5.270 * * * \\
(0.880)\end{array}$ & & $\begin{array}{c}4.819 * * * \\
(1.260)\end{array}$ & $\begin{array}{c}4.315 * * * \\
(1.607)\end{array}$ & & $\begin{array}{c}4.565 \text { **** } \\
(1.183)\end{array}$ \\
\hline Net*SD & $\begin{array}{c}-2.559 * * * \\
(0.830)\end{array}$ & $\begin{array}{c}-1.152 * * \\
(0.544)\end{array}$ & & $\begin{array}{l}-1.868 \\
(1.244)\end{array}$ & $\begin{array}{c}-0.975 \\
(1.513)\end{array}$ & & $\begin{array}{l}-1.374 \\
(0.946)\end{array}$ \\
\hline LnGDP90 & & & $\begin{array}{l}72.947 * \\
(37.113)\end{array}$ & $\begin{array}{c}8.148 \\
(26.671)\end{array}$ & $\begin{array}{c}-9.031 \\
(37.045)\end{array}$ & & \\
\hline$(\operatorname{LnGDP90})^{2}$ & & & $\begin{array}{c}-4.641 * * \\
(2.164)\end{array}$ & $\begin{array}{l}-0.284 \\
(1.517)\end{array}$ & $\begin{array}{c}0.037 \\
(2.009)\end{array}$ & & \\
\hline Latin & & & & $9.405 * * *$ & & & \\
\hline America & & & & $(3.500)$ & & & \\
\hline Africa & & & & $\begin{array}{c}17.122 * * * \\
(6.518)\end{array}$ & & & \\
\hline Asia & & & & $\begin{array}{c}10.068 * \\
(5.075)\end{array}$ & & & \\
\hline NIC & & & & $\begin{array}{c}1.792 \\
(2.622)\end{array}$ & & & \\
\hline Sec85 & & & & & 0.025 & -0.065 & -0.025 \\
\hline & & & & & $(0.093)$ & $(0.078)$ & $(0.100)$ \\
\hline Land pc & & & & & $\begin{array}{l}3.700 * * * \\
(1383)\end{array}$ & & \\
\hline AgEmp & & & & & $-0.385 *$ & & \\
\hline & & & & & $(0.208)$ & & \\
\hline RLP & & & & & $2.629 *$ & & \\
\hline & & & & & $(1.519)$ & & \\
\hline CIVLIB & & & & & & $1.961 * *$ & 0.718 \\
\hline & & & & & & $(0.927)$ & (1.190) \\
\hline FNDP (LLY) & & & & & & 5.085 & 2.622 \\
\hline & & & & & & (6.161) & $(5.680)$ \\
\hline $\mathrm{N}$ & 33 & 33 & 33 & 33 & 31 & 29 & 29 \\
\hline$R^{2}$ & 0.441 & 0.706 & 0.351 & 0.775 & 0.773 & 0.547 & 0.677 \\
\hline Adjusted $R^{2}$ & 0.423 & 0.686 & 0.330 & 0.700 & 0.690 & 0.493 & 0.607 \\
\hline St. Error & 8.087 & 5.970 & 8.715 & 5.866 & 5.973 & 7.629 & 6.722 \\
\hline
\end{tabular}

Note: Standard errors in parentheses.

* significant at the $10 \%$ level

** significant at the $5 \%$ level

$* * *$ significant at the $1 \%$ level

We have used the sample reported in Table A.2. For the last three regressions, we have removed Taiwan and Puerto Rico, due to data availability. For the last two, we have also removed Hong Kong and Mexico. 
Table 6: Quintile Analysis

\begin{tabular}{|l|c|c|c|c|c|}
\hline & $\mathbf{Q 5 , 9 0}$ & $\mathbf{Q 4 , 9 0}$ & $\mathbf{Q 3 , 9 0}$ & $\mathbf{Q 2 , 9 0}$ & $\mathbf{Q 1 , 9 0}$ \\
\hline Constant & $113.357 *$ & 5.575 & -7.875 & -20.134 & $-22.370 * *$ \\
& $(57.570)$ & $(5.706)$ & $(10.497)$ & $(14.317)$ & $(10.338)$ \\
Q5,60 & 0.212 & & & & \\
& $(0.197)$ & & & & \\
Q4,60 & & 0.060 & & & \\
& & $(0.158)$ & & & \\
Q3,60 & & & $0.372 *$ & & \\
& & & $(0.191)$ & & \\
Q2,60 & & & & 0.009 & \\
& & & & $(0.208)$ & \\
Q1,60 & & & & & -0.164 \\
& & & & & $(0.187)$ \\
SD & $3.731 * *$ & -0.469 & $-1.231 * *$ & $-1.028 *$ & -0.491 \\
& $(1.575)$ & $(0.389)$ & $(0.473)$ & $(0.510)$ & $(0.425)$ \\
Net*SD & $-2.563 * * *$ & $0.462 * * *$ & $0.477 *$ & $0.973 * * *$ & $1.055 * *$ \\
& $(0.896)$ & $(0.112)$ & $(0.243)$ & $(0.291)$ & $(0.232)$ \\
LnGDP90 & $-9.440 *$ & $1.810 * *$ & $2.301 *$ & $3.563 * *$ & $3.176 * *$ \\
& $(5.257)$ & $(0.800)$ & $(1.238)$ & $(1.636)$ & $(1.084)$ \\
Sec85 & -0.047 & 0.015 & -0.001 & 0.027 & 0.025 \\
& $(0.065)$ & $(0.017)$ & $(0.021)$ & $(0.023)$ & $(0.016)$ \\
AgEmp & $-0.364 *$ & -0.054 & $0.091 *$ & $0.135 * *$ & $0.131 * * *$ \\
& $(0.189)$ & $(0.034)$ & $(0.048)$ & $(0.058)$ & $(0.036)$ \\
RLP & 1.490 & -0.600 & -0.227 & 0.537 & -0.512 \\
& $(1.875)$ & $(0.366)$ & $(0.550)$ & $(0.553)$ & $(0.364)$ \\
\hline N & 23 & 23 & 23 & 23 & 23 \\
$R^{2}$ & 0.823 & 0.787 & 0.850 & 0.763 & 0.706 \\
Adjusted $R^{2}$ & 0.757 & 0.707 & 0.794 & 0.674 & 0.596 \\
St. Error & 4.390 & 1.054 & 1.224 & 1.520 & 1.281 \\
\hline
\end{tabular}

Note: Standard errors in parentheses.

* significant at the $10 \%$ level

** significant at the $5 \%$ level

$* * *$ significant at the $1 \%$ level

Due to data availability, we have removed Indonesia, Japan, New Zealand, Pakistan, Panama, South Africa, Taiwan, Tanzania, Thailand, and Puerto Rico from all regressions. 
Table 7: Government Expenditure

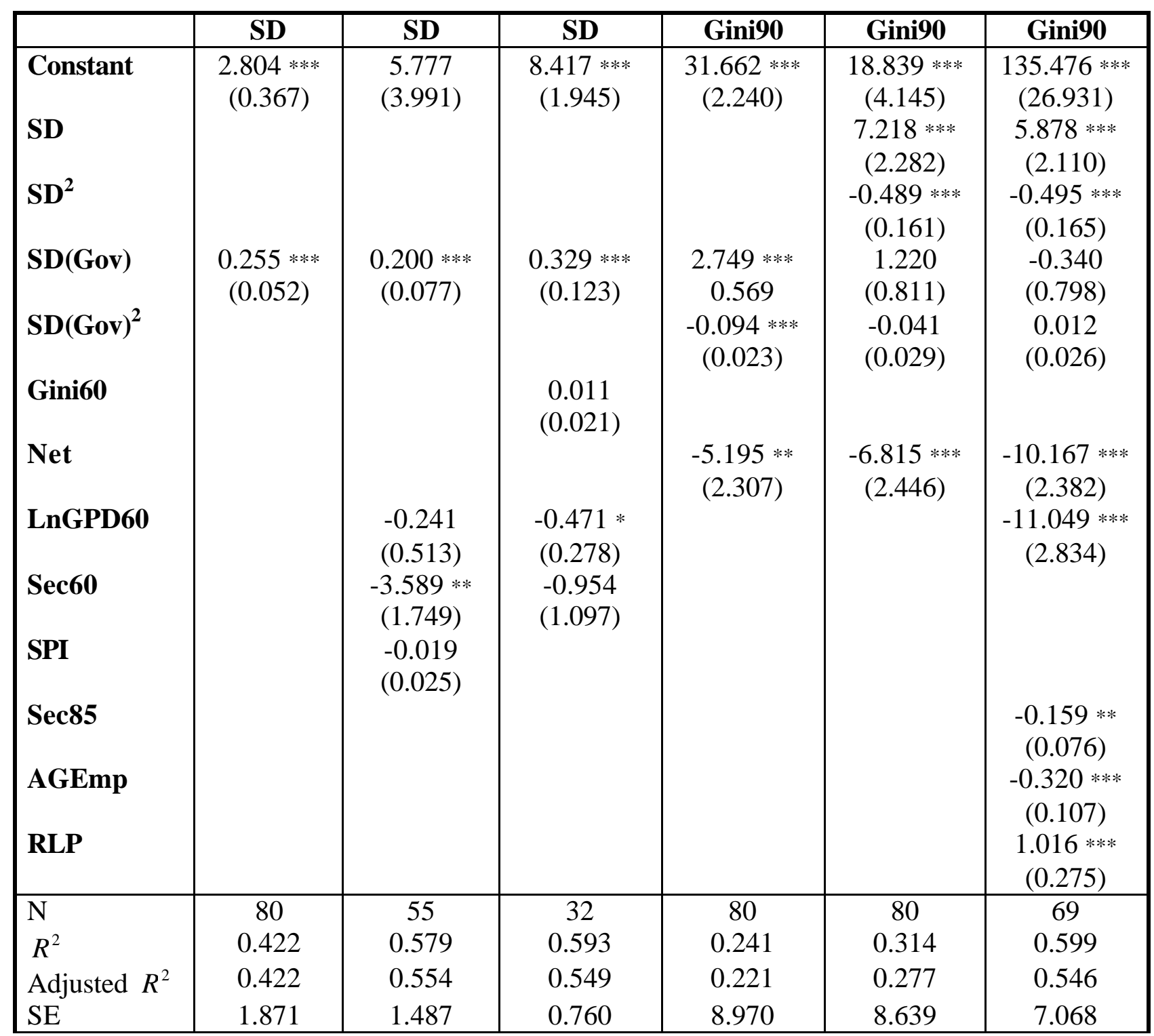

Note: Standard errors in parentheses.

* significant at the $10 \%$ level

** significant at the $5 \%$ level

*** significant at the $1 \%$ level

For regression 2, we have removed Algeria, Belgium, Burkina Faso, Central African Republic, Gambia, Ghana, Guatemala, Guinea, Guinea Bissau, Guyana, Hong Kong, Indonesia, Jordan, Korea, Lesotho, Luxembourg, Mali, Mauritius, Mauritania, Nepal, Nicaragua, Portugal, Puerto Rico, Singapore and Taiwan. Regression 3 uses the small sample, except Puerto Rico. For the last two regressions we have removed. For the last four regressions, we have removed Burkina Faso, Cote d'Ivoire, Egypt, Guinea, Luxembourg, Madagascar, Mauritania, Morocco, Nigeria, Puerto Rico, and Taiwan. 